\title{
A Study on Sutureless and Glue-free Conjunctival Autograft in Pterygium Surgery in A Tertiary Medical College Hospital
}

\author{
*AH Khan ${ }^{1}$, ZI Biswas ${ }^{2}$, MM Hossain ${ }^{3}$
}

\begin{abstract}
Background: Foreign material used in ocular surface surgery may lead to local complications such as discomfort, scarring, or infection. Plasma-derived products such as fibrin glue may produce hypersensivity reactions whereas the risk of viral transmission remains. We describe a simple method of achieving conjunctival autograft adherence during pterygium surgery avoiding potential complications associated with the use of fibrin glue or sutures.
\end{abstract}

Materials \& Methods: This study was conducted at Jahurul Islam Medical college Hospital, Bajitpur, Kishoregonj from August 2016 to April 2018. Fifty cases with unilateral primary pterygium were selected for the study. The operation was done under local anaesthesia. After pterygium excision and fashioning of the autologus conjunctival graft, the recipient bed is allowed to achieve natural haemostasis and relative dessication before graft placement. Excessive haemorrhage in the graft bed is temponaded. Graft adherence and positioning is examined after surgery.

Results: A total of 50 eyes of 50 patients mean age at the time of surgery was $40.5 \pm 10.3$ years ranged from 17 to 70 years, with a female to male ratio was $1: 1.94$, underwent sutureless glue-free autologus conjuntival graft after pterygium excision. Mean graft area was $24(1.5) \mathrm{mm}^{2}$. The patients were followed up for 4 months. Cosmesis was excellent in all cases and there were no intra- or post-operative complications requiring further treatment.

Conclusion: This simple technique for pterygium surgery may prevent potential adverse reactions encountered with the use of foreign materials and this small series provided safe and comparable results to current methods.

Key Words: Ocular surface, wound healing, conjunctiva, cornea.

\section{Introduction}

In 1985 kenyon et al. ${ }^{1}$ proposed that a conjuctival autograft of the bare sclera could be used in the treatment of recurrent and advanced pterygium. Recent reports favour the use of fibrin glue ${ }^{2-5}$ above sutures with improved comfort, decreased surgical time, reduced complication and recurrence rates have been reported. Suture-related complications include infection, granuloma formation, and chronic inflammation ${ }^{6,7}$ whereas plasma- derived fibrin glue has the potential risk of prion disease transmission and anaphylaxis in susceptible individuals.

\section{Materials and Methods}

This study was conducted at Jahurul Islam Medical college Hospital, Bajitpur, Kishoregonj from August 2016 to April 2018. Fifty cases with unilateral

$1 * D r$. Md. Anwar Hossain khan. Assistant Professor, Department of Ophthalmology, Jahurul Islam Medical College Hospital, Bajitpur, Kishoregonj. e-mail: dranwar0007@gmail.com

2Dr. A H M Zahirul Islam Biswas, Professor, Department of Ophthalmology, Jahurul Islam Medical College Hospital, Bajitpur, Kishoregonj

${ }^{3} \mathrm{Dr}$. Md. Mosharrof Hossain, Associate Professor, Department of Ophthalmology, Jahurul Islam Medical College Hospital, Bajitpur, Kishoregonj

*Corresponding Author

Date of submission: 11.06.2018 Date of acceptance: 08.10.2018

AKMMC J 2019; 10(1) : 28-31 
primary pterygium were selected for the study. The operation was done under local anaesthesia. After pterygium excision and fashioning of the autologus conjunctival graft, the recipient bed is allowed to achieve natural haemostasis and relative dessication before graft placement. Excessive haemorrhage in the graft bed is temponaded. Graft adherence and positioning is examined after surgery.

\section{Surgical Technique}

The body of the pterygium was dissected $4 \mathrm{~mm}$ from the limbus, down to bare sclera, and reflected over the cornea. The pterygium head and cap was avulsed using Hoskin's forceps and cleansing of the corneal remnants was done carefully by crescent knife. Only the thickened portions of the conjunctiva and the immediate adjacent and subjacent Tenon's capsule showing tortuous vasculature were excised. Excision of conjunctival plica and extensive dissection of Tenon's capsule were avoided. Haemostasis was allowed to occur spontaneously without the use of cautery, where possible. Seldom, if no blood was available to provide autologus fibrin, small perforating veins and capillaries were fractured to encourage a thin layer of fresh blood to cover the bare sclera. The size of the defect $\left(\mathrm{mm}^{2}\right)$ was measured with Castoviejo callipers. The limbal edge of the graft was carefully positioned at the host limbal tissue edge as described. ${ }^{7}$ No attempt was made to directly close the full extent of the excision wound, allowing natural graft positioning without tension. The scleral bed was viewed through the transparent conjunctiva to ensure residual bleeding did not relift the graft, small central haemorrhages were tamponaded with direct compression by non-toothed forceps / Iris repositor until haemostasis was achieved. The stabilization of the graft was tested with a merocel spear centrally and on each free edge to ensure firm adherence to sclera. Postoperatively steroid and antibiotic drops were instilled topically four times daily for 3 weeks.

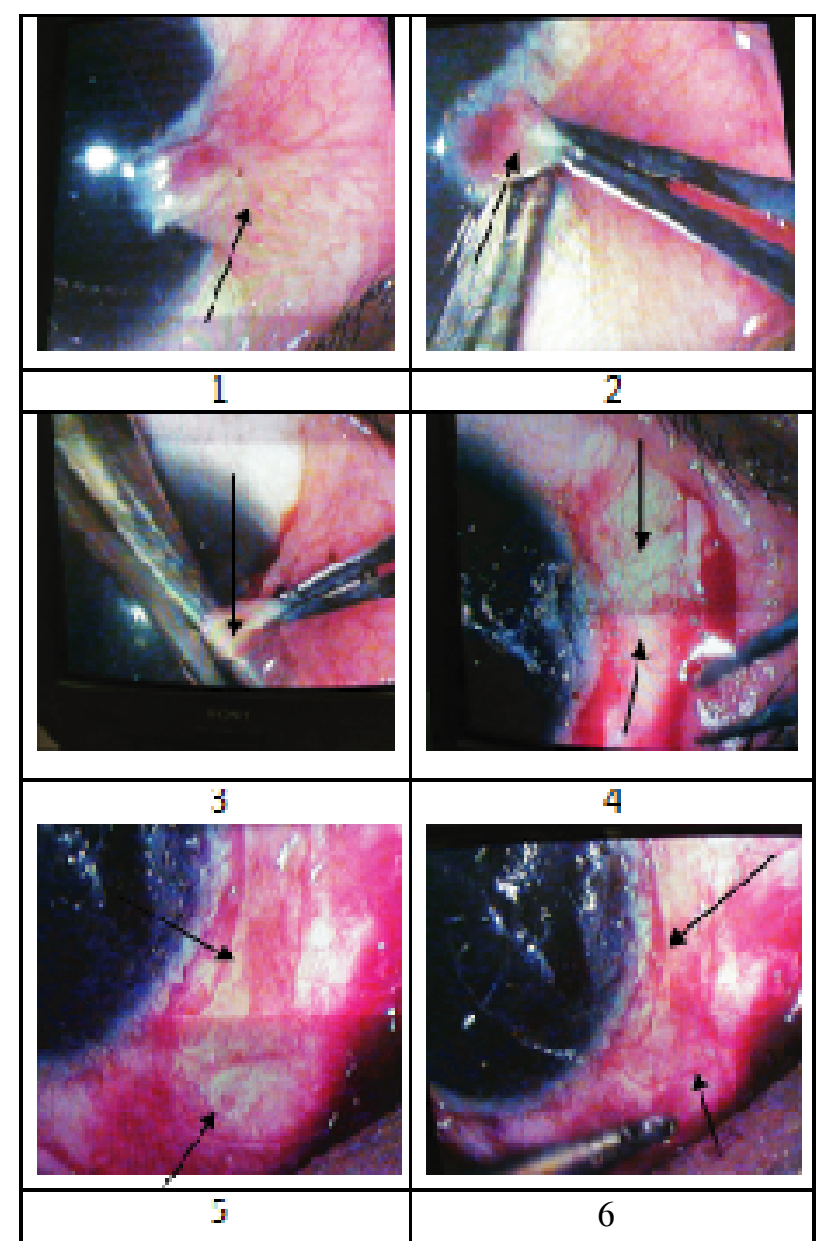

The above 6 Figures show: Fig. 1: Pterygium encroaching on the nasal side of right cornea. Figs. $2 \&$ 3: Excision of pterygium by holding its head with tissue forceps \& separating from the underlying cornea \& sclera by scissors \& the tissue remnants of pterygium are removed from the corneal surface by crescent knife.

Fig. 4: The bare sclera after excision of pterygium. Figs. 5 \& 6: Sutureless \& glue-free conjunctival autograft on the bare sclera.

\section{Results}

A total of 50 eyes of 50 patients, age at the time of surgery ranged from 17 to70 years, mean age $40.5 \pm 10.3$, underwent SGF autologus conjunctival graft after pterygium excision (Table 1). There were 17 female and 33 male patients with female to male ratio of 1:1.94. All patients had primary pterygium, 32 right eye and 18 left eye, 42 nasal sides and 8 temporal, and signed informed consent. Follow up time was weekly for the first one month, then every 
monthly for the next 3 months. Mean graft area was $24( \pm 1.5) \mathrm{mm} .{ }^{2}$ The mean surgical time was $16( \pm 1.6) \mathrm{min}$. There were no transplant dislocations or failures. There were no intra- or post-operative complications requiring further treatment. Visual acuities were not affected in the majority of patients. One patient with a large $5 \mathrm{~mm}$ pterygium reaching 1 $\mathrm{mm}$ away from the visual axis, \& another of $4.5 \mathrm{~mm}$ reaching $1.5 \mathrm{~mm}$ away from the visual axis, improved by 2 snellens chart lines each, after surgery (one $6 / 24$ to $6 / 12 \&$ the other $6 / 18$ to $6 / 9$ respectively). Cosmesis was excellent in all patients and photographic comparison of nasal to temporal conjunctiva at last review revealed no obvious cosmetic defects or recurrences (Table 2). Pain on the first post-operative day was consistently less and did not increase thereafter.

Table 1: Age distribution of the patients $(n=50)$ :

\begin{tabular}{cc}
\hline Age in years & No.of Patients (\%) \\
\hline $10-20$ & $02(4 \%)$ \\
$21-30$ & $10(20 \%)$ \\
$31-40$ & $20(40 \%)$ \\
$41-50$ & $08(16 \%)$ \\
$51-60$ & $06(12 \%)$ \\
$61-70$ & $04(8 \%)$ \\
Total & $50(100 \%)$ \\
\hline
\end{tabular}

Table 2: Results of sutureless and glue-free autologus conjunctival grafts in pterygium surgery.

\begin{tabular}{ll}
\hline No.of eyes & $\mathbf{5 0}$ \\
\hline OD & 32 \\
OS & 18 \\
Location & 42 nasal/ 8 temporal \\
Gender & 33 male / 17 female \\
Age range & 17 to 70 years \\
Age, mean \pm SD & $40.5 \pm 10.3$ years \\
Follow-up time & 4 months \\
Mean graft size,mean \pm SD & $24( \pm 1.5)$ mm. ${ }^{2}$ \\
Recurence & None \\
Visual improvement & 2 patients $(2$ snellen lines each $)$ \\
Complications & None \\
\hline
\end{tabular}

\section{Discussion}

Current surgical methods to prevent pterygium recurrence include conjunctival autograft, limbal and limbal-conjunctival transplant, conjunctival flap and conjunctival rotation autograft surgery, amniotic membrane transplant, cultivated conjunctival transplant, lamellar keratoplasty, and the use of fibrin glue. ${ }^{12}$ All of these techniques involve the use of sutures or fibrin glue and are therefore vulnerable to associated complications. The presence of sutures may lead to prolonged wound healing and fibrosis.4,6 Subsequent complications such as pyogenic granuloma formation are easily treated; others such as symblepharon formation, forniceal contracture, ocular motility restriction, diplopia, scleral necrosis, and infection are much more difficult to manage and may be sight threatening. ${ }^{13,14}$ Although generally considered safe, fibrin glues are currently manufactured from human plasma and therefore carry the risk of transmissible disease. ${ }^{12}$ Virus removal and inactivation procedures are included in the manufacturing process although may be of limited value against non-enveloped viruses such as hepatitis A virus and parvovirus B19. ${ }^{15}$ New devices that generate fibrin sealant from autologus blood may eliminate the current risks associated with pooled plasma. However they are not currently in widespread use and the time taken to procure the fibrin may be prohibited in day case pterygium surgery. ${ }^{16}$ Fibrinogen compounds may also be susceptible to inactivation by iodine preparations such as those used for conjunctival disinfection before pterygium surgery. ${ }^{17}$ The apposition of the lids to the bulbar conjunctiva provides a natural biological dressing and confers a unique woundhealing environment. Apart from a physical barrier, the lids provide compression, a smooth frictionless surface, and a vascular bed with immune capability in close proximity to the injury site. Our study has several limitations. It was non-randomised and consisted of a small study population and a relatively short follow-up period of 4 months. However, one article comparing four commonly used techniques for pterygium surgery reported mean time for appearance of any complication including recurrence was 4 months. ${ }^{19}$ Most 
importantly however, the operating time, postoperative symptoms, recurrence, and complication rate of the above-described technique (SGF) in our series appears to be equivalent to conventional suture and glue techniques of a similar follow-up duration. $3,4,6,10$ Specifically, the risk of graft retraction as described by $\operatorname{Tan}^{7}$ appears to be no greater without suturing or fibrin glue as long as meticulous dissection of the subepithelial graft tissue is respected. We postulate that as there is an even tension across the whole of the graft interface and no direct tension on the free graft edges (as might occur in sutures), there is reduced stimulus for subconjunctival scar tissue to form. Although surgical time in our small series appears no greater than current published literature, ${ }^{20}$ the possibility of longer operation times compared to sutures or fibrin glue is possible. A prospective randomized controlled trial is required to investigate the longterm efficacy of this SGF grafting technique in reducing recurrences.

Conflict of interest: The authors declared no conflict of interest.

\section{References}

1. Kenyon KR, Wagoner MD, Hettinger ME. Conjunctival autograft transplantation for advanced and recurrent pterygium. Ophthalmology 1985; 92: 1461-1470.

2. Ayala M. Results of pterygium surgery using a biologic adhesive. Cornea 2008; 27: 663-667.

3. Kim HH; Mun HJ, Park YJ, Lee KW, Shin JP. Conjunctivolimbal autograft using a fibrin adhesive in pterygium surgery. Korean $\mathbf{J}$ Ophthalmol 2008; 22: 147-154.

4. Koranyi G, Seregard S, Kopp ED. Cut and paste: a no suture, small incision approach to pterygium surgery. Br J Ophthalmol 2004; 88: 911-914.

5. Koranyi G, Seregard S, Kopp ED. The cut- andpaste method for primary pterygium surgery:longterm follow-up. Acta Ophthalmologica Scandinavica 2005; 83: 298-301.

6. Allan BD, Short P, Crawford GJ, Barrett GD, Constable IJ. Pterygium excision with conjunctival autografting: an effective and safe technique. Br J Ophthalmol 1993; 77: 698-701.
7. Tan D. Conjunctival grafting for ocular surface disease. Curr opin ophthalmol 1999; 10: 277-281.

8. Dorfman HS, Kennedy JE, Bird WC. Longitudinal evaluation of free autogenous gingival grafts. A four year report. J Periodontol 1982; 53: 349-352.

9. Sharma A, Moore J. Autologous fibrin glue for pterygium surgery with conjunctival autograft. Cont Lens Anterior Eye 2009; 32: 209.

10. Sebban A, Hirst LW. Pterygium recurrence rate at the Princess Alexandra Hospital. Aust NZJ Ophthalmol 1991; 19: 203-206.

11. Prabhasawat $\mathrm{P}$, Barton K, Burkett $\mathrm{G}$, et al. Comparison of Conjunctival autografts, amniotic membrane grafts, and primary closure for pterygium excision. Ophthalmology 1997; 104: 974-985.

12. Ang LP, Chua JL, Tan DT. Current concepts and techniques in pterygium treatment. Curr Opin Ophthalmol 2007; 18: 308-313.

13. Solomon A, Pires RT, Tsen SC. Amniotic membrane transpltation after extensive removal of primary and recurrent pterygia. Ophthalmology 2001; 108: 449-460.

14. Vrabec MP, Weisenthal RW, Elsing SH. Subconjunctival fibrosis after conjunctival autograft. Cornea 1993; 12: 181-183.

15. Groner A. Pathogen safety of plasma-derived products-Haemate P/Humate-P. Haemophilia 2008; 14(Suppl 5): 54-71.

16. Buchta C, Dettke M, Funovics PT, et al. Fibrin sealant produced by the CryoSeal FS System: product chemistry, material properties and possible preparation in the autologous preoperative setting. Vox Sang 2004; 86: 257-262.

17. Gilmore OJ, Reid C. Prevention of intraperitoneal adhesions: a comparison of noxythiolin and a new povidone-iodine/PVP solution. Br J Surg 1979; 66: 197-199.

18. Zhu X, Beuerman RW, Cheng ZY, et al. Kinetic analysis of conjunctival epithelial wound healing in the rabbit model. Invest Ophthalmol Vis Sci 2005; 46: 4247

19. Alpay A, Ugurbas SH, Erdogan B. Comparing techniques for pterygium surgery. Clin Ophthalmol 2009; 3: 69-74.

20. McLean C. Pterygium excision with conjunctival autografting. Br J Ophthalmol 1994; 78(5): 421. 